IZA DP No. 10141

Neoliberalization and the Changing Roles of Stakeholders in State-Led Shantytown

Redevelopment in Shenyang City, China

Xin $\mathrm{Li}$

Reinout Kleinhans

Maarten van Ham

August 2016 


\title{
Neoliberalization and the Changing Roles of Stakeholders in State-Led Shantytown Redevelopment in Shenyang City, China
}

\author{
Xin Li \\ Delft University of Technology \\ and Chinese Academy of Sciences \\ Reinout Kleinhans \\ Delft University of Technology \\ Maarten van Ham \\ Delft University of Technology \\ and IZA
}

Discussion Paper No. 10141

August 2016

IZA

P.O. Box 7240

53072 Bonn

Germany

Phone: +49-228-3894-0

Fax: +49-228-3894-180

E-mail: iza@iza.org

\begin{abstract}
Any opinions expressed here are those of the author(s) and not those of IZA. Research published in this series may include views on policy, but the institute itself takes no institutional policy positions. The IZA research network is committed to the IZA Guiding Principles of Research Integrity.

The Institute for the Study of Labor (IZA) in Bonn is a local and virtual international research center and a place of communication between science, politics and business. IZA is an independent nonprofit organization supported by Deutsche Post Foundation. The center is associated with the University of Bonn and offers a stimulating research environment through its international network, workshops and conferences, data service, project support, research visits and doctoral program. IZA engages in (i) original and internationally competitive research in all fields of labor economics, (ii) development of policy concepts, and (iii) dissemination of research results and concepts to the interested public.
\end{abstract}

IZA Discussion Papers often represent preliminary work and are circulated to encourage discussion. Citation of such a paper should account for its provisional character. A revised version may be available directly from the author. 


\begin{abstract}

\section{Neoliberalization and the Changing Roles of Stakeholders in} State-Led Shantytown Redevelopment in Shenyang City, China

Neoliberal politics in China have changed the roles of, and the interrelationships between, the state, the market and society in urban restructuring. Since 2008 , the central state has initiated the Shantytown Redevelopment Projects (SRPs) to improve the living conditions of low-income residents. Between 2008 and 2012, about 12.6 million households were involved in these national SRPs, and forced to move as their dwellings were demolished. This paper investigates how different stakeholders perceive and interact with each other in the state-led SRPs in Shenyang City in Northeast China. Through in-depth interviews with a range of stakeholders and analysis of policy documentation on SRPs, we find that there is a complex interplay between centralization, decentralization, marginalization of market forces, and the empowerment of residents in SRPs. The central government has replaced local governments in the initiation of redevelopment projects in disadvantaged neighbourhoods. District-level governments have replaced developers and municipal governments in land expropriation. Developers have become marginalized in SRPs and residents have become more empowered in the land expropriation taking place in urban redevelopment.
\end{abstract}

JEL Classification: O18, R23

Keywords: Shantytown redevelopment, neoliberalization, governance, demolition, China

Corresponding author:

Xin Li

OTB - Research for the Built Environment

Faculty of Architecture and the Built Environment

Delft University of Technology

P.O. box 5043

2600 GA, Delft

The Netherlands

E-mail: X.Li-6@tudelft.nl 


\section{Introduction}

Since 1978, neoliberalization in China has led to a commercialized housing provision system in which urban residential redevelopment has become strongly market-oriented (Shin, 2009). Driven by market mechanisms, developers and entrepreneurial local governments formed pro-growth coalitions, which have embarked on extensive urban housing demolition and redevelopment on profitable locations, featuring large-scale forced rehousing of residents ( $\mathrm{He}$ and $\mathrm{Wu}, 2007$ ). Neighbourhoods at the urban periphery and with low land values, have not received much attention from the state or the private sector. In 1998, the central government enacted a regulation to suspend the public housing provision system. From then on, those with a low income and those not eligible for state (or state-owned enterprise) housing subsidies had no, or very limited access to dwellings (Chen et al., 2014; Lee, 2000).

In 2008, in parallel with the local-state-initiated residential redevelopment projects, the central Chinese government initiated the first round of national Shantytown Redevelopment Projects (SRPs). SRPs aim at improving the living conditions of low-income residents and to stimulate the depressed housing market. In China, the term shantytown usually refers to neighbourhoods or areas with a high concentration of physically run-down dwellings, which lack basic infrastructures such as gas and water (MOHURD, 2013a). Some of the contemporary shantytowns were constructed by state-owned or collectively-owned enterprises to temporarily reside their employees and their family members in the era of planned economy. Due to a shortage of housing these areas were retained, but a lack of maintenance caused them to become dilapidated. The term shantytown is also used for dilapidated housing or illegally-constructed shanties in old inner cities, danwei $i^{1}$ communities or urban villages, or run-down villages in suburban and rural areas. SRPs involve the demolition of run-down neighbourhoods and the forced relocation of the residents. Between 2008 and 2012, about 12.6 million households were involved in the national SRPs (MOHURD, 2013a); their dwellings were demolished and they were forced to move. In 2013, the central state triggered a second round of SRPs, which focused especially on improving the living conditions of vulnerable residents in undesirable small scale urban areas. From 2008 until present, the neighbourhoods targeted for SRPs have changed from large-scale and welllocated, desirable neighbourhoods to small-scale neighbourhoods in undesirable locations (MOHURD, 2013b).

Neoliberalization in China has led to major changes in the roles and positions of stakeholders in urban restructuring activities. Entrepreneurial local governments, emerging market forces and self-enterprising individuals have developed into a state-market-society triad (He and Lin, 2015; Lin et al., 2014; Ong, 2007; Zhu, 1999). Each of these stakeholders behaves differently in response to 'the gaming between formal institutions (laws, rules, regulations) and informal institutions (norms/values, and traditions and routines)' (He and Lin, 2015: 2759). Some studies identify local governments, developers, and residents as the three main actors in urban redevelopment processes (He, 2012; Shin, 2009; Zhang, 2002). Other studies argue that while local 
governments and developers dominate urban redevelopment as land and capital providers respectively (He and $\mathrm{Wu}, 2005$; Shin, 2009; Zhang, 2002), residents and communities are becoming more disadvantaged and marginalized (He and Wu, 2007; Ren, 2014; Shin, 2014). Several studies and media reports show that disagreements over urban redevelopment projects in urban China are an important cause of conflicts between local governments or developers and sitting tenants (He, 2012; Hin and Xin, 2011; Si-chuan Sichuan News, 2009). Meanwhile, evolving regulations for the urban housing demolition and relocation are changing the interrelationships between the different actors in urban restructuring (Shih, 2010; Ren, 2014).

Most of the studies investigating urban restructuring projects in China have focussed on neighbourhoods with high land values in the context of a prospering housing market. Such projects have been very profitable for developers and local governments. Since the recession in the Chinese housing market after 2013, there have been few studies on urban restructuring in less popular areas for low-income residents. Little is known about how governments, developers and individuals perceive the redevelopment of these areas in China. Also, most of the urban redevelopment projects examined in empirical studies were carried out in a certain time period and therefore document the position of different stakeholders in one particular institutional, economic and social context. This tends to overlook changes in stakeholders' roles over time, because tracking their positions and interests over time was not within the scope of these studies. Some of the aforementioned case-based literature emphasizes how the relevant policies and regulations have influenced the behaviour of different stakeholders in urban restructuring. However, there is still a general lack of research on the evolution of related institutional contexts with regard to the roles of different stakeholders during urban restructuring in the era of neoliberalization in China.

This paper aims to understand how different stakeholders in the state-led SRPs perceive each other, and interact with each other, and how their role have changed over time. This paper discusses related urban and housing policies and regulations, and reports findings from semistructured interviews with stakeholders involved in the SRPs in Shenyang city, such as experts, governors, developers and residents. Shenyang City is an old industrial city in Northeast China and is the capital city of Liaoning Province. The city is a pioneer of SRPs in China. This remainder of this paper is structured as follows. The next section locates different stakeholders within the context of neoliberalized urban restructuring in China. Then the data, methods and research area are described. Following this, the paper discussed the changing roles of different stakeholders in SRPs in Shenyang city, by explaining the simultaneous centralization, decentralization, marginalization of market forces and empowerment of residents. The last section presents the conclusions. 


\section{Urban Restructuring in the Era of Neoliberalization in China}

Shantytown Redevelopment Projects (SRPs) are generally initiated and implemented by governments to improve the living conditions of low-income residents. Local governments or developers select the targeted neighbourhoods for SRPs. These neighbourhoods are demolished and residents are forced to move. They can usually get two types of compensation from governments or developers: monetary and/or in-kind compensation. Those who choose for in-kind compensation are moved to so-called relocation neighbourhoods (on site or off site), which are provided by local governments or developers. Residents who get monetary compensation may choose to purchase dwellings from the housing market. In urban China, SRPs are a type of urban restructuring policy program. SRPs involve major physical changes in run-down urban areas with the aim to improve the living conditions, and in some cases transform the urban function and social class of the population living in target areas. After 1978, neoliberalization in China kept changing the roles of and the interrelationships between the state, market and society in urban restructuring. SRPs explicitly manifest the changing roles of different stakeholders.

Neoliberalism, embedded in free market norms and market-based regulatory practices in capitalist countries, has become a norm for governance in many countries (Ong, 2007). Neoliberal practices aim at reducing state intervention, budget deficits and public debt, and prioritise the free market, capital accumulation and austerity (Harvey, 2005; Lin, 2014; Ong, 2007; Stilwell, 2014; Wang et al., 2012). Neoliberalization provides, on various scales, the private sector, individuals and the state more power, responsibility and freedom to 'maximize their own utility functions' (Hackworth and Moriah, 2006: 511; Wang et al., 2012). However, neoliberalization does not necessarily mean a continuous 'hollowing out of the state' and 'rolling out' of the market. In some contexts the state is still important in initiating, structuring and governing urban housing provision and restructuring projects, which are especially significant for disadvantaged social groups and less desirable residential areas (Brenner and Theodore, 2005; Dodson, 2006; Peck and Tickell, 2002; Swyngedouw et al., 2002; Uitermark et al., 2007; Xu and Yeh, 2009). This is in line with Ong's (2007) argument that neoliberalism, as ‘a migratory set of practices', is selectively adopted by different agents in different contexts with diverse forms, features and outcomes.

Neoliberalism and its related governance theories have been applied to studies on the logic, processes and governance arrangements between different actors in urban residential upgrading projects in post-reform China (He, 2012; Lee and Zhu, 2006; Lin, 2014; Lin et al., 2014; Zhang, 2002; Zhu, 1999). Since 1978, the Chinese government has adopted a series of neoliberalized interventions such as privatization, deregulation, decentralization, and marketization to establish a more market orientated economy (Harvey, 2005; He and Wu, 2009; Wu, 2010). Some argue that in response to neoliberalization, the state is changing its style of governance: from governing a 'totalitarian society' or 'authoritarian society' to 'ruling from afar' (Wu, 2008; Zhang and Ong, 2008). This transition is clearly evident in housing and residential upgrading projects. In the socialist era, the state took public housing provision as an inherent duty, and state-owned 
enterprises or other state organizations provided their employees with highly subsidized housing. In the post-reform era, a neoliberalized housing market was established. Currently, it is said that access to housing in China is largely dependent on a household's income and whether people qualify for subsidized housing provided by the state or work units (Chen et al., 2014; Lee, 2000; Stephens, 2010: 2970; Wang et al., 2012). Some scholars pointed out that this excludes vulnerable social groups that can neither afford commodity dwellings nor obtain access to subsidized housing (Chen et al., 2014; Lee, 2000). Some authors argue that the lack of access to housing for the poor shows the dysfunction of the neoliberalized Chinese housing market (Meng, 2012; Ni et al., 2012). The neoliberalized housing market in China appears to follow a classic process also seen in traditional capitalist countries, which involves reducing state public services for disadvantaged social groups, while at the same time stimulating a commercialized housing market (Chen et al., 2014; He and Wu, 2009: 299; Stephens, 2010).

However, neoliberalization and marketization in China have produced complicated interrelationships between and within different stakeholders in urban restructuring projects (He and Lin, 2015). Despite the neoliberalization trend in Asian countries, or countries undergoing a transition from a socialist economy to a market economy, the central government often has a strong influence on urban governance (Lin, 2014; Ong, 2007; Stephens, 2010; Wu, 2008). Some scholars argue that neoliberalism in China was selectively adopted as a set of practices, and that it has not undermined the state's strong control on resource allocation, national policies, and public service delivery (Cartier, 2013; He and Wu, 2009; Ong, 2007; Wu, 2010). "The Chinese case may show that under some specific conditions neoliberalization may have to consolidate rather than reduce control” (Wu, 2008: 1093). In China the central state has adopted social and political stability and economy development as the underlying principles for the formulation of policy direction, and the state will intervene, or even 'temporarily ease the radical neoliberal progresses', if market failure erodes social stability (Chen et al., 2014; He and Wu, 2009: 297; Wang et al., 2012). This is reflected in the resurgence of public housing projects led by the Chinese central government since the global financial crisis. The state aims at establishing a 'harmonious society' by addressing income gaps, reducing social inequality, and boosting the economy (Chen et al., 2014; Stephens, 2010).

Moreover, under neoliberalization within the one-party system, the relationship between the central and local governments has shifted. Generally speaking, local governments are supposed to follow the directives of the central government for projects such as public housing construction (Wang et al., 2012). Despite strong hierarchical governance, there is asymmetrical decentralization of power and responsibility, and local governments are reluctant to invest in public housing sectors which has caused public housing projects to lag behind (Lin, 2014; Stephens, 2010; Xu and Yeh, 2009). Fiscal and economic reforms have given local governments more autonomy in economic activities, and also increased the pressure to generate more fiscal revenue for the provision of public services such as social housing and health care (Chen et al., 2014; Chien, 2007; Lin, 2014). Some have even argued that neoliberalization has changed the nature and function of local 
governments. Motivated by economic growth, the need to upgrade their urban image and career aspiration of governments cadres and officials, local governments now often behave like entrepreneurs (Lin, 2014; Zhu, 1999). It has been argued that many local governments have transformed from social welfare providers to acting like 'developmental', 'localism' and 'entrepreneurialised' states (He, 2012; He and Wu, 2005; Su, 2014; Yang and Chang, 2007; Zhang, 2002; Zhu, 1999).

Apart from the state, which is responsible for making guidelines and balancing conflicts between social stability and the neoliberalized economy, stakeholders in the market and society (such as developers and residents) are also affected by neoliberalized urban restructuring governance. In many cases, local governments and developers have held a dominant position in urban redevelopment (He and Wu, 2005; Shin, 2009; Zhang, 2002), while residents are more disadvantaged and marginalized (Ren, 2014; Shih, 2010; Shin, 2014). Sometimes even the compensation criteria have not been transparent to local residents, and forced relocatees have been excluded from the decision-making process (He and Wu, 2005; Yang and Chang, 2007: 1822). Conflicts between local governments or developers and homeowners constantly arise due to disagreement on urban redevelopment projects and compensation (He, 2012; Hin and Xin, 2011; Si-chuan Sichuan News, 2009).

The neoliberalization process in China has enriched the agents involved and affected the ways these agents behave in urban restructuring projects. Since 2008, the central government has initiated two rounds of Shantytown Redevelopment Projects (SRPs), with the aim of improving the living conditions of low-income residents and stimulating local housing markets. At the same time, the enactment and amendment of policies and regulations on land expropriation, capital raising and land (re)development have affected the behaviour of the state, developers and residents. This raises questions about how different stakeholders perceive and interact with each other in the SRPs. Taking Shenyang City as a case study, this paper investigates how the roles of central government, local governments, developers and residents have changed over time in state-led SRPs. The paper also shows how the various levels of government, market and society interact with each other in current urban restructuring and public housing projects. Before presenting the analyses, the next section explains the methods and data used.

\section{Data, Methods and Research Area}

The empirical basis for this paper consists of policy documentation and in-depth, semi-structured interviews conducted in March and April 2015. We approached governors, planners, developers and scholars via email, personal introduction or the local government's official channels, and we also interviewed residents living in shantytowns or rehousing neighbourhoods in Shenyang city. All the interviews were conducted face-to-face using a semi-structured interview schedule which varied depending on the type of respondent. The issues discussed with the governors, planners, 
developers and scholars focused mainly on how the SRPs in Shenyang City were implemented in terms of financial issues, land expropriation, governance arrangement; how and why different actors took part in the SRPs, and their interrelationships and problems which arose in the implementation process. We also interviewed residents because we believe that knowing how residents perceive and experience SRPs will contribute to a better understanding of the nature, practice and outcomes of regulations or policies. Twenty-three interviews were conducted in total, including seventeen interviews with scholars, governors, planners and developers, four with individual residents and two with focus groups of residents. The interviews with governors, planners and experts were recorded and all interviews with residents but one were recorded, enabling content analysis of the transcriptions. Some respondents were approached a second time to obtain supplementary information. To guarantee the anonymity of respondents in the analysis, quotes are indicated by respondent number and their respective function. Alongside the interviews, we analysed relevant policy documentation on SRPs in general and their implementation in our case study area Shenyang City in particular.

Most of the research on urban restructuring projects in China focuses on eastern coastal cities such as Beijing, Shanghai, and Guangzhou. Our case study city is Shenyang City in Northeast China, a typical old industrial city. Shenyang has a population of 5.25 million (SSB, 2014), making it the largest city in Northeast China and the 11th largest city in the whole country. Shenyang has been called the 'Ruhr of the East', and it was deeply affected by the planned economy. The city has a large proportion of state-owned enterprises, industrial workers and danwei communities. However, since 1978, Shenyang has undergone a major economic depression because of its maladjustment to the market economy. Many enterprises went bankrupt and workers were laid off. Urban areas, especially those industrial areas occupied by state-owned enterprises and danwei communities, became problematic areas. Since the 1990s, the municipal authority of Shenyang has implemented several residential upgrade projects to improve the living conditions of its citizens. Shenyang City is the capital city of Liaoning Province, which is the first province to implement SRPs at the provincial level, a development strategy pursued by Premier Li when he was the Governor of Liaoning Province. As the capital city of Liaoning Province, Shenyang has been a pioneer in SRPs in the province both before and during the period from 2005 to 2008, and it has a lot of experience with SRPs. Shenyang is therefore a very interesting case study for investigating changes in governance arrangements in SRPs over time. 


\section{Changes in SRPs in Shenyang: Centralization, decentralization, marginalization of market forces, and empowerment of residents}

The implementation of SRPs in Shenyang has changed with the changing social, economic and institutional context. By analysing policy documentation and data from our interviews, we identified four key changes in the implementation of SRPs; 1) centralization in governance; 2) decentralization in governance; 3) marginalization of market forces; and 4) the empowerment of residents.

\subsection{Centralization process of the SRPs in Shenyang}

There is a tendency towards centralization in Shenyang's SRPs with regard to initiating projects, raising funds and expropriating land. As table 1 shows, SRPs in Shenyang used to be initiated by the Shenyang municipality. The central government has taken over this role from 2013 onwards. Since the 1980s, Shenyang has seen some local-state initiated residential redevelopment projects (Guo and Sun, 2010). In 2000, Shenyang municipality initiated a large-scale urban shantytown redevelopment programme (Guo and Sun, 2010). Shenyang municipality adopted a new strategy in which 'Projects are operated according to market mechanisms, and supported by the governments' (Guo and Sun, 2010: 110), which emphasizes redeveloping shantytowns and land at market prices. This strategy implies the key role of market forces such as that of developers in raising funds and redeveloping projects, and illustrates the importance of partnerships between market forces and governments in the SPRs during the early 2000s. In 2005, the then Governor of Liaoning Province launched a provincial-wide SRP programme, incorporating SRPs into its provincial-level development strategy for the first time. Shenyang City was encouraged by the policies of the provincial authority, to implement larger-scale SRPs in the following two years (Guo and Sun, 2010). The centralization process of SRPs did not stop at the provincial level. During the period 2005-2008, central government officials visited the relocation neighbourhoods of SRPs in Liaoning Province and spoke highly of the SPRs in Liaoning. SRPs were first mentioned by the central government in 2007, when it announced its national policy "Solve the housing problems of urban low-income social groups". However, from 2008 to 2013, Shenyang launched few SRPs within its inner city because there were hardly any shantytowns left in the inner city (source: Respondent, planner, 00).

In 2013, Shenyang commenced a five-year SRP (2013-2017) in response to the central government's promotion of a second-round of SRPs. In order to motivate local governments and get them involved in SRPs, the central state repeatedly stressed the importance of SPRs as the key to economic growth and the welfare of residents in the current situation of slow economic growth (Li, 2015). The central government set clear plans for the SRPs regarding finance arrangements, governance in land acquisition, and compensation schemes for residents. Also several nationallevel meetings were organized between officials from different provinces and municipalities to exchange experiences with SRPs. The central state has also monitored and supervised the use of 
state-supported funds and to promote the pace of SRPs uptake. Shenyang City had stated that there were no urban shantytowns left within the inner city after 2008. However, in response to the central government's strong promotion of SRPs, Shenyang extended the targeted neighbourhoods from shanty neighbourhoods in the inner city to shanty villages at the urban periphery (source: respondents, planner 00 and governor 20).

Through other related policy interventions, the central state controls the crucial factors for the implementation of SRP: capital (funds) and land. Thus, the local governments have had to align their development strategies within the agenda of the central government to obtain more financial and policy support. Since 2011, the central government has enacted several policies related to funds, urban space and land expropriation. We explain three policies in more detail.

The first policy concerned the land (re)development patterns. It emphasized compact land development and stressed the redevelopment of land already in use rather than uncultivated land (MLRPRC, 2014). Consequently, local governments have had to increase land use efficiency via redeveloping inner cities if they require more land. The redevelopment of urban shantytowns has become an important option for increasing land use efficiency (source: respondent, planner, 00).

The second policy is related to the funding resources for local developments. The central government published the regulation 'Control on the risk of the local governments' debt' in 2014, which sought to limit local governments' risk in raising capital by pledging urban land to banks for loan (source: respondents, governor 20 and 26). The depressed housing market and the low financial capacity of residents in shantytowns worsen the funding of SRPs. Local governments have to rely on financial support from the central government to promote SRPs. Funds for Shenyang's SRPs originate from different-level governments and the China Development Bank $\left(\mathrm{CDB}^{2}\right)$. Up to 2015, Shenyang has received RMB 73.11 million in funds from the central government which are meant for compensating residents in SRPs. The CDB further provided Shenyang RMB 12.2 billion for SRPs in 2015 and 2016, which accounts for almost 80\% of the total investment that Shenyang requires.

Third, the central government instructs local governments to regulate the land expropriation process via legislation and regulations. In 2007, the central government enacted the Property Rights Law which highlights the protection of private properties. In 2011, the central government abolished the No. 305 regulation on land expropriation (issued in 2001) which implies the legality of forced demolition on private properties and which is in contradiction with the Property Rights Law (The State Council of PRC, 2001; Weinstein and Ren, 2009). At the same time, the new regulation on land expropriation (No. 590) was issued to standardize the conversion of property ownership and land-use rights from homeowners to local governments in public-use projects. These changes show the centralization in local urban (re)developments. 
Table 1. The centralization process of SRPs in Shenyang

\begin{tabular}{|c|c|c|c|c|}
\hline Year & Initiative & Related projects and policies & $\begin{array}{c}\text { Feature of } \\
\text { neighbourhoods }\end{array}$ & $\begin{array}{l}\text { Strategy adopted } \\
\text { in Shenyang City }\end{array}$ \\
\hline $\begin{array}{l}2001- \\
2004\end{array}$ & $\begin{array}{l}\text { Shenyang } \\
\text { City }\end{array}$ & $\begin{array}{l}\text { City-level residential upgrading } \\
\text { projects; the pace of SRPs was } \\
\text { accelerated since the central state } \\
\text { launched the "Revitalization of the } \\
\text { Northeast old industrial bases } \\
\text { programme" in } 2003\end{array}$ & \multirow{3}{*}{$\begin{array}{l}\text { Large scale; } \\
\text { spatially } \\
\text { concentrated, } \\
\text { relatively good } \\
\text { location }\end{array}$} & $\begin{array}{l}\text { Projects are } \\
\text { operated according } \\
\text { to market } \\
\text { mechanisms, and } \\
\text { supported by the } \\
\text { various } \\
\text { governments }\end{array}$ \\
\hline $\begin{array}{l}2005- \\
2008\end{array}$ & $\begin{array}{l}\text { Liaoning } \\
\text { Province }\end{array}$ & $\begin{array}{l}\text { SRPs listed as the chief project of } \\
\text { Liaoning Province's development } \\
\text { strategy; }\end{array}$ & & $\begin{array}{l}\text { Market } \\
\text { functioning, } \\
\text { government } \\
\text { initiated }\end{array}$ \\
\hline $\begin{array}{l}2009- \\
2012\end{array}$ & $\begin{array}{l}\text { The central } \\
\text { government }\end{array}$ & $\begin{array}{l}\text { "Urban shantytown redevelopment" } \\
\text { was first mentioned in the national } \\
\text { policy and was on the agenda of } \\
\text { national public housing; involving a } \\
\text { RMB } 4 \text { trillion worth of investment in } \\
\text { infrastructure construction since the } \\
\text { global finance crisis. }\end{array}$ & & ----- \\
\hline $\begin{array}{l}2013- \\
2017\end{array}$ & $\begin{array}{l}\text { The central } \\
\text { government }\end{array}$ & $\begin{array}{l}\text { Shantytown redevelopment projects } \\
\text { have become more independent projects }\end{array}$ & $\begin{array}{l}\text { Small scale; } \\
\text { spatially } \\
\text { scattered; } \\
\text { relatively poor } \\
\text { location }\end{array}$ & $\begin{array}{l}\text { Government } \\
\text { oriented, and } \\
\text { district-level } \\
\text { governments are } \\
\text { responsible }\end{array}$ \\
\hline
\end{tabular}

Sources: based on own interview materials and relevant policies and regulations

\subsection{Decentralization process of the SPRs in Shenyang}

While the initiation and financing of SRPs are centralized, the expropriation of land and implementation of SRPs are decentralized in Shenyang City. This is partly due to the institutional arrangements of the central government and Liaoning Province. In order to regulate urban housing demolition, in 2011 the central government abolished the old regulation (No. 305) on demolishing urban housing, and issued a new one (No. 590) emphasizing the expropriation of state-owned land for public use. The new regulation has changed the land transfer process and abolished the demolition permit (Figure 1.4). The emphasis is on the local governments' duty in urban redevelopment (see Figures 1.1 and 1.3). In the previous regulation (Figure 1.2), a demolition permit was needed before buildings could be demolished and land expropriated. This permit was issued by the municipal housing bureau, and it included key information such as the scale of demolitions, the evictor and the deadline for housing demolitions. The decision-making on expropriating land has devolved from the Shenyang municipal-level government to the districtlevel governments. In China, the administrative structure in urban areas is: municipal government, 
district-level governments and the sub-district governments. So district-level governments are a lower level than municipal governments.

"During the time that No. 305 regulation was in force (2001-2011), the municipallevel department was responsible for the management [of demolishing housing and compensating residents] ...The municipal department issued demolition permit [to evictors]... In the era of No. 590 regulation, district-level governments are responsible for expropriating land” (respondent, governor, 31).

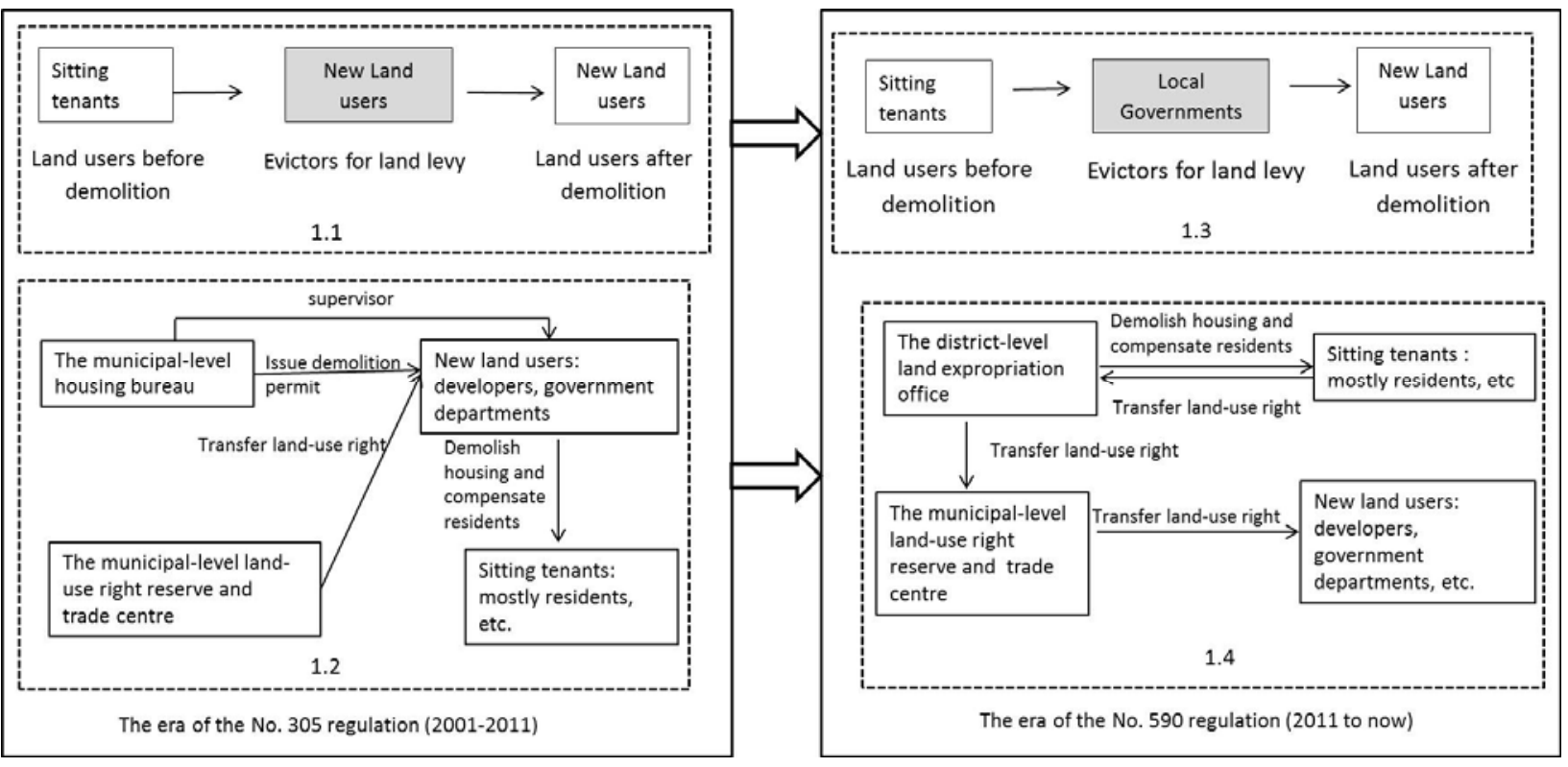

Figure 1. Changes in the land expropriation process: Regulations No. 305 and No. 590 Sources: Based on regulations No. 305 (The State Council of PRC, 2001) and No.590 (The State Council of PRC, 2011)

In 2013, Liaoning Province introduced a policy to devolve more power to district-level governments with regard to project management, urban planning, land-use management and land expropriation. At about the same time, Shenyang municipality adopted a policy which emphasized the leading role of district-level governments in implementing SRPs. District-level governments can decide on the duration of the transitional period, the criteria for compensation and the procedure for the selection of rehousing dwellings in practice, as is shown in the following interview quote:

"In the period 2001-2005, it had been the municipal-level government implementing (SRPs) ... And each district-level government was responsible for demolitions. In the period 2013-2017, each district-level government is responsible [for SRPs], [including] loans, funds, land expropriation, demolition and rehousing” (respondent, governor, 20). 
District-level governments also take charge of the preliminary selection of neighbourhoods targeted for redevelopment, and decide the redevelopment strategy in practice. For instance, a district-level government in Shenyang adopted a strategy which consolidated small-scale projects into larger ones in the redevelopment of a small scale and spatially scattered shanty neighbourhood (People's Daily, 2013). In most cases, the district-level land expropriation offices or housing bureaus play a leading role in implementing SRPs.

"This shantytown redevelopment office is a temporary office, and it is affiliated to our Land Expropriation and Compensation Office here. The common situation of shantytown redevelopment here is as follows: the sub-district office is the chief, and the land expropriation office is responsible for the policy guidance... The [shantytown redevelopment] project [implementation] group consists of staff from sub-district offices, who are responsible for signing contracts [with residents], visiting residents, investigation, negotiation and so on" (Respondent, governor, 45).

\subsection{The marginalization of market forces: More government and less market}

In the new round of SRPs in Shenyang, market forces (impersonated by developers) have largely become marginalized with regard to initiating, financing and expropriating land. Market forces used to play a significant role in investing in SRPs (expert, 333). The booming real estate market has enabled land to become the main financial resource for SRPs (SSB, 2004, 2007,2008). During 2005-2008, Shenyang municipality raised its funding for SRPs mainly through the market, that is, by transferring the land-use rights from the government to developers at market prices or by pledging land to banks for loans (Guo and Sun, 2010). A report about Liaoning Province's SRPs during 2005-2006 shows that about RMB 1.9 billion (which is the equivalent of $€ 195.6$ million) was invested in Shenyang's SRPs, almost all of these funds were raised through the market (RGDUFE: 53). This clearly echoes the "market functioning, government initiating" strategy, and indicates the partnership between governments and developers in SRPs. However, since 2013, the national housing market has gone into an economic recession. Developers are less keen about investing in real estate and obtaining more land, which is illustrated below:

"Currently developers are faced with more challenges and difficulties. This is because of the entire housing market situation [recession], rather than the [increasing] difficulty of expropriating a piece of land... The 'golden decade' of real estate development is over, and now it is the 'silver era'... [Developers'] interest in real estate development has decreased... Developers are less motivated to acquire more pieces of land." (Respondent, developer, 221). 
Hence, developers are less interested in neighbourhoods targeted for SRPs, because these neighbourhoods are in poor locations and are small scale, and their profit margins are much less favourable compared with the redevelopment of inner-city areas:

"The developments are totally based on market behaviour. If developers can profit from a project, then they will participate in the project... Now developers are not interested in the [redevelopment of] shantytowns. [Developers] only focus on earning money" (Respondent, developer, 331). "If the location of shantytowns is good then it is good for developers... It costs too much to redevelop shantytowns [in poor locations]" (Respondent, developer, 467).

Due to the housing market recession, developers are less motivated to participate in SRPs. Moreover, they can hardly take part in the current land expropriation process entailed in SRPs. Figure 1 shows how the position and interaction between developers, residents and different-level governments have changed due to the changes in land expropriation regulations. In the era of the old regulation (Figure 1.2), developers got involved in land expropriation after obtaining the demolition permit from related municipal-level departments. Under the current regulation (Figure 1.4), developers are excluded from the land expropriation process, and only local governments are responsible for compensating and rehousing residents. The institutional changes mentioned above have marginalized developers' role in SRPs, and developers no longer directly initiate or finance SRPs as they did before. However, developers are not totally excluded from SRPs. They are indirectly taking part in SRPs, through local government's purchase of their dwellings for rehousing relocatees. This has come about because one of the key targets of SRPs is the stimulation of local housing markets. The central government encourages local governments to buy commodity dwellings for relocatees, so as to consume the redundant housing in stock and boost the housing market (source: respondent, expert, 312).

\subsection{The empowerment of residents in SRPs}

Land expropriation is one of the key processes in SRPs, and it concerns transferring land-use rights from sitting tenants to local governments. The new regulation changes the position of residents in land expropriation in the second round of SRPs. Residents are entitled to more rights in the decision-making concerning SRPs. Local governments have to consult relocatees' opinions on (re)development projects and compensation criteria, and make corresponding changes based on public opinion. At the same time, the consensus of residents (in shantytowns) targeted with the redevelopment is one of the considerations that district-level governments have to take into account, when they select neighbourhoods for SRPs (SYG, 2014). This is because the degree of residents' acceptance of the project affects the cost and duration of implementation of SRPs, as is explained by one of the interviewed governors: 
"[In a recent SRP] When the government asked the public for their opinion...Because residents don't agree with the compensation [offered by the government], we'd better suspend the project ... In the past [before the enactment of the new regulation], once the project caught the interest of governments, regardless of the agreement or disagreement of residents, it is possible [for government] to launch [the project] " (respondent, governor, 31).

In practice, it is much easier to carry out procedures backed by regulations. For instance, local governments have to make compensation criteria public as stipulated by the new regulation which aims at putting a transparent compensation process in place, because the 'fairness' of the compensation matters a lot to residents and they cannot bear to 'get less than what other residents get' (respondent, governor, 37). However, the new regulation is unable to address the opposition of residents to SRPs and cannot solve the conflicts and complications caused by land expropriation in SPRs.

"Land expropriation means that you have to interact with residents. It is hard and it can easily cause conflicts. The regulation is perfect, but the practice is difficult." (Respondent, governor, 33).

In fact, during urban restructuring, the 'nail household' (a household that refuses to move) phenomenon is more than an issue of land expropriation. Rather, it is a complex social issue (Respondent, governor, 61). In some cases, low income families use the SRP in an attempt to solve housing accommodation problems, as is illustrated by the following example:.

"My son has become an adult now and it is time for him to date someone... We of course want this place to be redeveloped. However if it [the compensation] is not reasonable, I am not willing to move... It is very important that they compensate my son with an apartment... The size of the apartment for my son should be $70 \sim 80 \mathrm{~m}^{2}$, so in the future the apartment is big enough for him, his wife and their kid/s" (respondent, resident, 74).

Although the new regulation enhances the rights of residents affected by land expropriation, little is known about the extent to which residents are involved in the decision-making process. The empowerment of residents is a concern for local governments in the implementation of SRPs.

“Residents' legal awareness is increasing, and they will go to court for a decision ... [which] increases the cost of the project, causes a delay in the project and harms the reputation of governments. The residents who left earlier also have complaints, and they have criticized the government for the long transitional period... this causes many 
conflicts for the subsequent redevelopment projects [initiated by governments].”

(Respondent, governor, 51).

The regulations empower residents to influence the decision-making and the implementation of land expropriation and SRPs. However, local governments still dominate the process of SRPs, including the selection of target neighbourhoods, the decisions on compensation criteria and implementation procedures. Also, the problems encountered by local governments and the many appeals of households involved in SRPs show that the physical interventions, compensation criteria and governance structures cannot solve various social issues that appear in the context of the relocation that is triggered by SRPs.

\section{Conclusions}

This paper has examined how the central government, local governments, developers and residents perceive and behave in SRPs in Shenyang. It found that the implementation of SRPs showed a tendency towards centralization in providing funds, initiating projects and governing land. Meanwhile, SRPs have also undergone decentralization. District-level governments rather than the municipality or developers now dominate land expropriation in SRPs. Developers play a less important role in funds provision or land expropriation, and the newly issued land expropriation regulation provides residents more rights in the decision-making surrounding land expropriation. Against the above backdrop, the less popular shantytowns have been experiencing state-led redevelopment. However, current SRPs focus more on physical improvements of dwellings and adopt unique compensation criteria for sitting tenants. This may be at the expense of other important issues that residents have, such as job opportunities and family living arrangement. Usually, it is these issues related to residents' life chances rather than their physical living conditions that determine the smoothness of implementing SRPs.

The complex interactions between various stakeholders in SRPs in Shenyang illustrate the multifaceted issues surrounding neoliberalization in China: a market mechanism combined with strong state control, and the increasing role of society (Lin and Zhang, 2014; Wu, 2010). Governments, especially the central government, still play a dominant role in guiding national activities over the past few decades of neoliberalization in China. Although the state has assigned part of its responsibility for providing public services to the market and individuals, it still retains its influence and responsibilities on the delivery of public welfare services. The initiation of SRPs not only brings benefits to vulnerable residents, but it also has economic implications. From the resurgence of public housing policies and the two rounds of SRPs since 2008, we can see that the state has been using investment in the public sector as a key strategy to cope with the threats of the global financial crisis and slow economic growth. Chinese neoliberalism is therefore more like a set of governance practices which the state has selectively adopted, structured and promoted, instead of an outcome of market or global forces. Meanwhile, the SPR and related regulations 
demonstrate the state's effort to balance the conflicts between social stability and economic development. Although several advanced capitalist countries, such as the UK and the Netherlands, also retain control of public service delivery, most of their interventions are less direct compared with China (Dodson, 2006).

However, the significant role of the state in China does not mean that neoliberalism has little influence on stakeholders in public and private sectors involved in urban restructuring. Neoliberalism has cultivated the private sector and self-enterprising individuals in China. Affected by the market, residents, local governments and developers behave in a business-like manner. Also, the interactions between different levels of government and various stakeholders have become complicated and continue to change. In the context of neoliberalization and housing market recession, governments, and especially the central government, are obligated to provide social services for the public, and to take both people's wellbeing and economic growth into account ( $\mathrm{Li}$, 2015). Moreover, it is necessary to make corresponding governance arrangements and follow operational practices which boost the smoothness of SRPs, because SRPs are faced with more complicated and comprehensive social issues as neoliberalization becomes more firmly entrenched in China.

\section{Notes}

1: "A work unit (danwei) generally refers to a special kind of workplace in the context of state socialism where the workplace becomes an extension of the state apparatus and undertakes the function of social organisation and control” (Wu, 1996: 1604). Work units not only took the responsibility of production and offering job opportunities. They also function as a social organization which provided employee services and welfare such as housing, education, hospital, canteen, and sports fields (Bjorklund, 1986; Wang and Chai, 2009).

2: China Development Bank is a financial institution in the People's Republic of China (PRC) under the direct jurisdiction of the State Council. As one of three policy banks of the PRC, it is primarily responsible for funding large infrastructure projects (Wikipedia, 2015).

\section{References}

Bjorklund E. (1986) The Danwei: socio-spatial characteristics of work units in China's urban society. Economic Geography: 19-29.

Brenner N and Theodore N. (2005) Neoliberalism and the urban condition. City 9(1): 101-107.

Cartier C. (2013) Neoliberalism and the Neoauthoritarian City in China-Contexts and Research Directions: Commentary in Conversation with Jennifer Robinson's Urban Geography Plenary Lecture. Urban Geography 32(8): 1110-1121. 
Chen J, Yang Z and Wang YP. (2014) The New Chinese Model of Public Housing: A Step Forward or Backward? Housing Studies 29(4): 534-550.

Chien S. (2007) Institutional innovations, asymmetric decentralization, and local economic development: a case study of Kunshan, in post-Mao China. Environment and Planning C 25(2): 269.

Dodson J. (2006) The "Roll" of the State: Government, Neoliberalism and Housing Assistance in Four Advanced Economies. Housing, Theory and Society 23(4): 224-243.

Guo Y and Sun G. (2010) Century changes-spatially concentrated urban shantytown redevelopment in Liaoning, Beijing: The History of the Communist Party of China Press.

Hackworth J and Moriah A. (2006) Neoliberalism, Contingency and Urban Policy: The Case of Social Housing in Ontario. International Journal of Urban and Regional Research 30(3): 510-527.

Harvey D. (2005) A brief history of neoliberalism, New York: Oxford University Press.

He S. (2012) Two waves of gentrification and emerging rights issues in Guangzhou, China. Environment and Planning A 44(12): 2817-2833.

He S and Lin GC. (2015) Producing and consuming China's new urban space: State, market and society. Urban Studies 52(15): 2757-2773.

He S and Wu F. (2005) Property - led redevelopment in post - reform China: a case study of Xintiandi redevelopment project in Shanghai. Journal of Urban Affairs 27(1): 1-23.

He S and Wu F. (2007) Socio-spatial impacts of property-led redevelopment on China's urban neighbourhoods. Cities 24(3): 194-208.

He S and Wu F. (2009) China's Emerging Neoliberal Urbanism: Perspectives from Urban Redevelopment. Antipode 41(2): 282-304.

Hin LL and Xin L. (2011) Redevelopment of urban villages in Shenzhen, China - An analysis of power relations and urban coalitions. Habitat International 35(3): 426-434.

Lee J. (2000) From Welfare Housing to Home Ownership: The Dilemma of China's Housing Reform. Housing Studies 15(1): 61-76.

Lee J and Zhu Y-p. (2006) Urban governance, neoliberalism and housing reform in China. The Pacific Review 19(1): 39-61.

Li K. (2015) Li Keqiang: How can we achieve social justice if the shantytown problems are not solved. Available at: http://www.gov.cn/xinwen/2015-06/17/content 2880958.htm (accessed 17 June 2015).

Lin GC and Zhang AY. (2014) Emerging spaces of neoliberal urbanism in China: Land commodification, municipal finance and local economic growth in prefecture-level cities. Urban Studies 52(15): 2774-2798.

Lin GCS. (2014) China's landed urbanization: neoliberalizing politics, land commodification, and municipal finance in the growth of metropolises. Environment and Planning A 46(8): 1814-1835.

Lin Y, Hao P and Geertman S. (2014) A conceptual framework on modes of governance for the regeneration of Chinese 'villages in the city'. Urban Studies 52(10): 1774-1790.

Meng X. (2012) The transformation of Modi Community: The redevelopment and community governance in the deprived neighbourhoods in inner city, Beijing: Renming University Press. 
MLRPRC. (2014) The guideline of the MLRPRC on promoting the efficient utilization of land. Available at: http://www.mlr.gov.cn/zwgk/zytz/201409/t20140926 1331065.htm (accessed 26 September 2014). MOHURD. (2013a) Decoding the suggestions on accelerating the redevelopment of the shantytowns from the state council. Available at: http://www.gov.cn/zwhd/2013-07/12/content_2445702.htm (accessed 12 July 2013).

MOHURD. (2013b) It really matters to improve the living condition of people:Interview with the Vice Minister of MOHURD. Available at: http://www.mohurd.gov.cn/bldjgzyhd/201309/t20130909_ 214987.html (accessed 12 September 2013).

Ni P, Oyelaran-Oyeyinka B and Chen F. (2012) Probe into the development mode of Low-income settlements in the urbanization process : the experience of shanty towns reconstruction in Liaoning, China, Beijing: Social Sciences Academic Press (China).

Ong A. (2007) Neoliberalism as a mobile technology. Transactions of the Institute of British Geographers 32(1): 3-8.

Peck J and Tickell A. (2002) Neoliberalizing Space. Antipode 34(3): 380-404.

People's Daily. (2013) Model. Observation for the frontline of economy: Huanggu District of Shenyang, Combining both hands in shantytowns redevelopment. People's Daily, 17 September 2013

Ren X. (2014) The Political Economy of Urban Ruins: Redeveloping Shanghai. International Journal of Urban and Regional Research 38(3): 1081-1091.

RGDUFE. The theory, practice and evolution of the urban shantytown redevelopments in Liaoning province. The research group of Dongbei University of Finance and Economics.

Shih MI. (2010) The Evolving Law of Disputed Relocation: Constructing Inner-City Renewal Practices in Shanghai, 1990-2005. International Journal of Urban and Regional Research 34(2): 350-364.

Shin HB. (2009) Residential Redevelopment and the Entrepreneurial Local State: The Implications of Beijing's Shifting Emphasis on Urban Redevelopment Policies. Urban Studies 46(13): 2815-2839.

Shin HB. (2014) Urban spatial restructuring, event-led development and scalar politics. Urban Studies 51(14): 2961-2978.

Si-chuan News. (2009) Report about the demolition and self-burning event in Chengdu city. Si-chuan News, 3 September 2009

SSB. $(2004,2007,2008)$ Shenyang Statistical Yearbook, Beijing: China Statistic Press.

SSB. (2014) Shenyang Statistical Yearbook (2014), Beijing: China Statistic Press.

Stephens M. (2010) Locating Chinese Urban Housing Policy in an International Context. Urban Studies 47(14): 2965-2982.

Stilwell F. (2014) Neoliberalism in the City: Economic Theory, Class Interests and Political Practices. Housing, Theory and Society 31(1): 42-47.

Su X. (2014) Urban entrepreneurialism and the commodification of heritage in China. Urban Studies 52(15): 2874-2889.

Swyngedouw E, Moulaert F and Rodriguez A. (2002) Neoliberal urbanization in Europe: large-scale urban development projects and the new urban policy. Antipode 34(3): 542-577. 
SYG. (2014) Informs of People's Government of Shenyang city on the redevelopment plan of the SRPs in Shenyang city in 2014. Available at: http://www.shenyang.gov.cn/zwgk/system/2014/03/12/ 010090651.shtml (accessed 7 February 2014).

The State Council of PRC. (2001) The Regulation on the Management of the Demolition of Urban Dewellings. Available at: http://www.gov.cn/gongbao/content/2001/content 60912.htm (accessed 13 June 2001).

The State Council of PRC. (2011) The regulation on the expropriation and compensation of dwellings on the state-owned land Available at: http://www.gov.cn/flfg/2011-01/21/content 1791480.htm (accessed 21 Jan 2011).

Uitermark J, Duyvendak JW and Kleinhans R. (2007) Gentrification as a governmental strategy: social control and social cohesion in Hoogvliet, Rotterdam. Environment and Planning A 39(1): 125-141.

Wang D and Chai Y. (2009) The jobs-housing relationship and commuting in Beijing, China: the legacy of Danwei. Journal of Transport Geography 17(1): 30-38.

Wang YP, Shao L, Murie A, et al. (2012) The Maturation of the Neo-liberal Housing Market in Urban China. Housing Studies 27(3): 343-359.

Weinstein L and Ren X. (2009) The changing right to the city: urban renewal and housing rights in globalizing Shanghai and Mumbai. City \& Community 8(4): 407-432.

Wikipedia. (2015) China Development Bank. Available at: https://zh.wikipedia.org/ wiki/\%E5\%9B\%BD\%E5\%AE\%B6\%E5\%BC\%80\%E5\%8F\%91\%E9\%93\%B6\%E8\%A1\%8C (accessed 12 April 2015).

Wu F. (1996) Changes in the structure of public housing provision in urban China. Urban Studies 33(9): 1601-1627.

Wu F. (2008) China's great transformation: Neoliberalization as establishing a market society. Geoforum 39(3): 1093-1096.

Wu F. (2010) How Neoliberal Is China's Reform? The Origins of Change during Transition. Eurasian Geography and Economics 51(5): 619-631.

$\mathrm{XuJ}$ and Yeh A. (2009) Decoding urban land governance: state reconstruction in contemporary Chinese cities. Urban Studies 46(3): 559-581.

Yang Y-R and Chang C-H. (2007) An Urban Regeneration Regime in China: A Case Study of Urban Redevelopment in Shanghai's Taipingqiao Area. Urban Studies 44(9): 1809-1826.

Zhang L and Ong A. (2008) Privatizing China: socialism from afar. New York: Cornell University Press.

Zhang T. (2002) Urban Development and a Socialist Pro-Growth Coalition in Shanghai. Urban Affairs Review 37(4): 475-499.

Zhu J. (1999) Local growth coalition: the context and implications of China's gradualist urban land reforms. International Journal of Urban and Regional Research 23(3): 534-548. 